\title{
PATH ANALYSIS ON THE ASSOCIATIONS BETWEEN STRESS, POLYCISTIC OVARIUM SYNDROME, AND THE RISK OF INFERTILITY IN FEMALE OF REPRODUCTIVE AGE
}

\author{
Suci Arsita Sari'), Uki Retno Budihastuti²), Eti Poncorini Pamungkasari3) \\ 1)Masters Program in Public Health, Universitas Sebelas Maret \\ 2)Department of Obstetrics and Gynecology, Dr. Moewardi Hospital, Surakarta \\ 3) Faculty of Medicine, Universitas Sebelas Maret
}

\begin{abstract}
Background: Polycystic ovary syndrome (PCOS) is a disorder that associates with an imbalance in female sex hormones. It represents $80 \%$ of anovulatory infertility cases. The purpose of this study was to examine factors associated with the risk of infertility among female of reproductive age using path analysis model.

Subjects and Method: A case control study was carried out in Dr. Moewardi hospital, Surakarta, from May to July 2019. A sample of 200 women was selected by fixed disease sample. The dependent variable was infertility. The independent variables were PCOS, body mass index (BMI), lifestyle, age, stress, metabolic syndrome, endometriosis, and myoma uterine. The data were obtained from medical record and questionnaire. The data were analyzed by path analysis run on Stata 13 .

Results: Infertility among women was directly and positively affected by age $\geq 35$ years old $(b=2.20 ; 95 \% \mathrm{CI}=0.95$ to $3.44 ; \mathrm{p}=0.001), \mathrm{BMI}>25(\mathrm{~b}=2.11 ; 95 \% \mathrm{CI}=0.81$ to 3.41 ; $\mathrm{p}=0.001)$, endometriosis $(\mathrm{b}=1.61 ; 95 \% \mathrm{CI}=0.16$ to $3.06 ; \mathrm{p}=0.029)$, myoma uterine $(\mathrm{b}=$ $1.88 ; 95 \% \mathrm{CI}=0.56$ to 3.20$)$, metabolic syndrome $(\mathrm{b}=2.73 ; 95 \% \mathrm{CI}=1.39$ to $4.07 ; \mathrm{p}$ $<0.001)$, PCOS $(\mathrm{b}=4.76 ; 95 \% \mathrm{CI}=2.33$ to $7.19 ; \mathrm{p}<0.001)$, and employment $(\mathrm{b}=2.11$; $95 \% \mathrm{CI}=0.81$ to $3.41 ; \mathrm{p}=0.001)$. It was indirectly affected by high stress and lifestyle.

Conclusion: Infertility among women is directly and positively affected by age $\geq 35$ years old, BMI >25, endometriosis, myoma uterine, metabolic syndrome, PCOS, and employment. It is indirectly affected by high stress and lifestyle.
\end{abstract}

Keywords: infertility, polycistic ovarium syndrome, path analysis

\section{Correspondence:}

Suci Arsita Sari. Masters Program in Public Health, Universitas Sebelas Maret. Jl. Ir. Sutami 36A, Surakarta 57126, Central Java. Email: suciarsita@gmail.com. Mobile: 085786179994. 